\title{
Resonans mellem livets afslutning og livets begyndelse
} En ubetrådt sti til sundhed $i$ svangreomsorgen?

Christina Prinds ${ }^{1}$, Dorte Hvidtjørn² \& Lene Moestrup ${ }^{3}$

cpri@ucsyd.dk

${ }^{1}$ University College Syddanmark og Syddansk Universitet

${ }^{2}$ Klinisk Jordemoderspecialist på Aarhus Universitetshospital

${ }^{3}$ Afdeling for Anvendt Sundhedsforskning

Prinds, Chrstina; Hvidtjørn, Dorte; Moestrup, Lene (2019). 'Resonans mellem livets afslutning og livets begyndelse: En ubetrådt sti til sundhed i svangreomsorgen?' i Tidsskrift for Forskning i Sygdom og Samfund, nr. 30. 175-197.

Denne artikel er en sekundær analyse og diskussion af to forskningsprojekter, som søgte at udforske eksistentielle karakteristika ved henholdsvis livets begyndelse (blandt nybagte mødre) og livets afslutning (blandt døende og deres pårørende). På baggrund af empiri genereret via forskellige forskningsmetoder diskuteres resultaterne i lyset af en frllesteoretisk forståelse af sekulære, religiøse og spirituelle aspekter i menneskelivet. I artiklen fokuserer vi $i$ særlig grad på, hvordan det at blive mor kan aktualisere eksistentielle overvejelser og hvordan resonansen til samme aktualisering $i$ forbindelse med døden, kan informere sundhedsvæsenets svangreomsorg. Med begrundelse $i$ to sammenfattende argumenter, det eksistentielle/åndelige og det sundhedsfaglige, argumenterer vi for, at eksistentiel og andelig omsorg potentielt kan være relevant ved livets begyndelse på samme vis som ved livets afslutning. 
Resonance between beginning of life and end of life: An un-trodden path to health in Maternity Services?

This paper presents a secondary analysis and discussion of two research projects, which separately explored existential aspects of beginning of life (among first time mothers) and end of life (among dying and their relatives) respectively. Findings from two studies conducted in different research designs are discussed through common theoretical understandings of secular, spiritual and religious aspects of life. In the paper we focus in particular on, how becoming a mother can actualize existential considerations and how the resonance to the same actualizations in relation to dying, can potentially inform maternity services. Two summary arguments, the existential-spiritual and the health professional argument substantiate our reason to emphasize how spiritual care might be as relevant at beginning of life, as it is at end of life.

Empty-handed I entered

the world

Barefoot I leave it

My coming, my going -

Two simple happenings

that got entangled.

Kozan Idikyo 1360 ("Jisci")

\section{Vikling mellem livets begyndelse og livets slutning}

Så tidligt som i år 1360 reflekterer haikudigteren over, hvordan livets begyndelse og livets afslutning er viklet ind i hinanden ved begge to at være simple og nøgne begivenheder. De peger på hinanden ved at åbenbare livet i dets simpelhed, men måske også ved, at det er livet selv, som ligger imellem dem. Denne vikling synes at være tydelig for haikudigteren. I mellemtiden er vi måske blevet blinde for, hvordan dødens nærvær nogle gange kan få livet til at være mest nærværende og omvendt; hvordan livets begyndelse (fødslen) nogle gange kan gøre døden mere synlig? Udgangspunktet for denne artikel er netop refleksioner over viklingen af 
eksistentielle overvejelser ved livets begyndelse og livets afslutning i to danske studier.

Nyere sundhedsvidenskabelige studier peger på aspekter, som kan være tilstede ved både oplevelser med døden og med fødslen, og som på hver sin vis understreger simpliciteten ved fødsel og død: Det kan være erfaringen af kroppens uforudsigelighed forstået som både styrke og svaghed. Det kan være fornemmelsen af, at "klokke"-tid kan opleves ophævet ved både fødsel og død, hvor tiden er sin egen og ikke måles i timer og minutter. Ligeledes er en form for eksistentiel ydmyghed i mødet med død eller fødsel beskrevet flere steder. Livet synes simpelthen mere intenst både i fødsels- og dødssituationer og også i tiden efter fødslen. På den måde kommer både oplevelsen af fødsel og død til at fungere som livsperspektiverende (Callister, 2004; Crowther, Smythe, \& Spence, 2014; Hodgkinson, Smith, \& Wittkowski, 2014; Kaufman \& Morgan, 2005; Miller, 2005). Artiklen tager udgangspunkt $\mathrm{i}$ to forskningsprojekter som med forskellige metodiske tilgange søgte at udforske eksistentielle karakteristika ved henholdsvis livets begyndelse og livets afslutning (Moestrup, 2015; Prinds, 2014). Flere gange i vore individuelle forskningsprocesser overraskedes vi over, hvordan de empiriske fund fra projekterne bøjede sig imod hinanden: I det ene projekt huskede nogle døende minder fra tiden med deres spædbørn, og i det andet projekt blev døden tilsyneladende mere nærværende for de kvinder, som netop havde født. Formålet med nærværende artikel er gennem en sekundær analyse af resultater fra vore to studier at vise, hvordan eksistentiel og åndelig omsorg potentielt kan være relevant på sammenlignelige måder ved livets begyndelse og ved livets afslutning.

I vores udforskning af eksistentielle aspekter af det at være enten døende eller pårørende til en døende og det at være nybagt mor, anvendte vi i de to forskningsprojekter det samme teoretiske fundament for eksistentiel orientering. Dette teoretiske fundament er piloteret i en dansk, sekulær kontekst og vil blive udfoldet $\mathrm{i}$ det følgende afsnit.

Endvidere vil vi søge at udfolde hvilke organiserende forståelser af eksistentielle orienteringer, der findes i dokumenter fra den danske sundhedsstyrelse og WHO i relation til slutningen på livet. Der er flere grunde til at inddrage disse officielle dokumenters forståelse af eksistentielle aspekter: Dels fordi deres forståelser ofte fungerer som retningsanvisende i udarbejdelsen af praktiske guidelines, men også fordi de udtrykker vidensorienteringer. De officielle dokumenter er samtidig en del af vore studiers fælles fundament, fordi begge studier har grund i en sundhedsfaglig klinisk kontekst, som ofte henviser til sådanne dokumenter. 
Endnu et fælles fundament for udarbejdelsen af begge studier er den voksende mængde videnskabelige studier, som peger på sammenhænge mellem sundhed og eksistentiel orientering, som betydende både for sundhed forstået som helbred, men også for sundhed $\mathrm{i}$ bred forstand forstået som at kunne mestre sygdom og sundhed. (Bussing, Janko, Baumann, Hvidt, \& Kopf, 2013; Koenig, King, \& Carson, 2012; Schnell, 2009).

\section{Eksistentiel eller åndelig?}

I udforskningen af fænomener relateret til komplekse fænomener som mening og eksistens synes det væsentligt allerede indledningsvis at klargøre, hvordan vi anvender begreberne eksistentiel og åndelig: I den analytiske og teoretiske tilgang i vores studier har vi anvendt begrebet eksistentiel som et "overbegreb", der kan omhandle både sekulære, religiøse og/eller spirituelle aspekter af livet. I forbindelse med beskrivelser relateret til klinisk sundhedsarbejde har vi imidlertid valgt at anvende det to-leddede samlende begreb "eksistentiel og åndelig", idet de officielle dokumenter fra den danske sundhedsstyrelse bruger netop dette begreb i forsøget på at rumme såvel sekulært eksistentielle, religiøse eller spirituelle aspekter af menneskelivet. Argumenter for disse valg vil blive yderligere udfoldet i de følgende nedenstående afsnit.

\section{Eksistentielle orienteringer: Mening med livet}

At reflektere over meningen med livet er i denne artikel funderet i europæisk eksistensfilosofisk tradition, som væsentligst drejer sig om livet selv - at være til og reflektere over hvad det vil sige at være i live (Binswanger, 1963; Frankl, 1963; Jacobsen, 2007). Den danske filosof Søren Kierkegaard forstås ofte som eksistensfilosofiens grundlægger. Kierkegaard menes at have været inspireret af en maieutisk tanke om at hjælpe sine samtidige til at gøre egne eksistentielle refleksioner. Maieutik betyder fødselshjælper og sigter til en forståelse af filosofi som en proces, hvori man kan hjælpe sit medmennesket til at bringe egne refleksioner til live (Sokrates 469 fvt-399 fvt). En maieutisk proces kan således ses som en slags filosofisk fødselshjælperproces, og begrebet har også været fortolket som inspireret af Sokrates' mor, som var jordemoder (Birkler, 2010; Hansen, 2016; Kierkegaard, 1962). Forskellige eksistensfilosofiske tænkere har gennem tiden udviklet forskel- 
lige kategoriseringer for, hvilke fundamentale livsspørgsmål man som menneske konfronteres med, som f.eks. søgen efter mening i livet eller erkendelsen af dybest set at være alene. (Jacobsen, 2007; van Deurzen-Smith, 1984; Yalom, 1980). Fundamentale livsspørgsmål aktualiseres let ved store livsbegivenheder - som for eksempel fødsel og død (Brudal, 2000; Budin, 2001; Vries, 1981).

Mening med livet kan indebære forskellige eksistentielle orienteringer, der kan indeholde både sekulære filosofiske refleksioner og praksisser, men som også kan være spirituelle og religiøse. De spirituelle og religiøse orienteringer indebærer typisk noget transcendent. Transcendens omtales hos antropologen Rubow og teologen Johannesen-Henry som en overskridelse af det "denne verdenslige" og er således rettet mod noget $i$ en anden verden. En sådan anden verden er ikke nødvendigvis præget af hverken kristne eller vestlige videnskabelige forståelser, men kan være præget af helt andre kosmologier fra for eksempel buddhisme, indiansk kultur eller nordisk mytologi. Refleksioner over mening med livet kan således hente forundrings- og forklaringskraft fra mange forskellige orienteringer, som kan trives hos det enkelte menneske på samme tid. Rubow og Johannesen-Henrys forståelse af transcendens viste sig relevant i vores analytiske arbejde, da også de har anvendt det i en sekulær, sundhedsfaglig kontekst, som ligner vores: Hos deltagerne i vores projekter viste det sig, at forestillinger om transcendens trivedes, fordi fødsel og død er livsbegivenheder, der kan skabe forbindelse til noget transcendent og dermed forvandle livet for en stund (Rubow \& Johannessen-Henry, 2010).

\section{Eksistentielle orienteringer: Organiserende forståelser fra sundhedsstyrelsen og WHO}

Eksistentiel orientering og betydningen for sundhed synes væsentligt $\mathrm{i}$ både verdenssundhedsorganisationen $\mathrm{WHO}$ og den danske sundhedsstyrelses indsats for svært syge og døende og deres pårørende. Livskvalitet er et væsentligt sundhedsmål og blev i 2002 defineret af WHO i den palliative indsats, som fokuserer på svært syge og døende patienter og deres pårørende. Indsatsen må omfatte "... smerter og andre problemer af både fysisk, psykisk, psykosocial og åndelig art." (Sundhedsstyrelsen, 2017 s. 6). Hvad åndelig art indebærer uddybes allerede i Sundhedsstyrelsens faglige retningslinjer for den palliative indsats fra 1999: "Det åndelige" aspekt af palliativ omsorg omfatter et menneskes basale opfattelse af kernen i tilværelsen, oplevelsen 
af hvad det $i$ egentlig forstand betyder at være menneske og forståelsen af livsværdier. Således vil "spiritual care" i palliativ sammenhæng skulle forstås som "eksistentiel og åndelig omsorg". (Sundhedsstyrelsen, 1999). Endvidere opfordres der i anbefalingerne fra 2017 specifikt til, at der i den initiale behovsvurdering spørges systematisk ind til fysiske, psykiske, sociale og eksistentiellelåndelige behov hos såvel patienten selv, som hos pårørende. Der er altså fokus på en systematisk indsats for at opnå det overordnede formål om både at fremme livskvaliteten samt forebygge og lindre lidelse af eksistentiel art (Sundhedsstyrelsen, 2017 s. 15-16). Det understreges, at der er en flydende overgang mellem almene eksistentielle eller åndelige spørgsmål og tro. Det væsentlige i indsatsen er at turde adressere eksistentielle/åndelige emner og undersøge om og hvordan, der kan være ressourcer eller udfordringer, og finde ud af hvilken mening disse har i patientens livshistorie (Sundhedsstyrelsen, 2017 s. 46). Det understreges, at palliation ikke er et lægefagligt speciale, men består af flere specialer, foruden en generel tværfaglig indsats. Derfor kræver feltet ligeledes eksterne samarbejdspartnere som f.eks. præster eller repræsentanter fra andre trossamfund. Det indebærer koordination af såvel den uddannelsesmæssige opgave (både på basalt og højtspecialiseret niveau), samt i relation til forskning og udvikling i relation til særlige behov (som f.eks. eksistentielle/åndelige behov og viden om disse) (Sundhedsstyrelsen, 2017 s. 14).

Eksistentiel orientering og betydningen for sundhed synes ikke væsentligt i hverken verdenssundhedsorganisationen WHO eller den danske sundhedsstyrelses indsats i forbindelse med graviditet, fødsel og barsel (Sundhedsstyrelsen, 2013; World Health Organization, 2016). I den nyeste anbefaling fra WHO fokuseres dog på at skabe en positiv oplevelse af graviditet, fødsel og barsel, herunder også at kommunikere empatisk med respekt for sociokulturelle behov og kvinders værdighed (World Health Organization, 2016). Udeblivelsen af eksistentielle eller åndelige behov i officielle dokumenter forbindelse med svangreomsorgen berører vi i diskussionen.

\section{Eksistentielle orienteringer: Forskningsfeltet i DK}

En sundhedspraksis, som indebærer eksistentiel/åndelig omsorg, må nødvendigvis forudgåes af videnskabelig udforskning af tanker og praksisser om eksistentiel orientering og mening hos såvel patienter som sundhedsprofessionelle. Den videnskabelige udforskning besværliggøres imidlertid af, at menneskers eksistentielle og religiøse overvejelser i særlig grad kan være private i Danmark, som 
har været beskrevet som meget lidt religiøst (Rosen, 2009; Zuckerman, 2008). På baggrund af de europæiske værdiundersøgelser, som foretages med jævne mellemrum også i Danmark, beskrives danskernes tro som aftraditionaliseret og individualiseret i modsætning til andre vestlige samfund som f.eks. USA (Andersen \& Lüchau, 2011; Zuckerman, 2008). Indenfor de seneste år har mere end 10 danske forskningsprojekter med tilknytning til forskningsnetværket "Nordic Research Network of Faith and Health" øget indsigten i danske patienters og pårørendes eksistentielle og åndelige behov, og i hvordan sundhedsprofessionelle både forstår og håndterer disse behov. Studierne tyder på, at mødet med sygdom kan intensivere eksistentielle overvejelser - som også kan have religiøs eller spirituel karakter. Studierne understreger endvidere de førnævnte fortolkninger af værdiundersøgelserne; at mening og eksistens sjældent drøftes med andre - end ikke med nærmeste familie eller venner (Health, 2017).

På baggrund af en omfattende gennemgang af forskellige teoretiske forståelser af, hvad der konstituerer eksistentiel mening, foreslog religionspsykolog la Cour og teologen Hvidt i 2010 en model: "Meaning-Making Matrix" (MMM) (la Cour \& Hvidt, 2010) (se model 1). Modellen bygger på den amerikanske sociolingvist Joshua A. Fishmans identitetstermer knowing, doing og being relateret til etnisk identitet (Fishman, 1980). Hos la Cour og Hvidt handler modellen om eksistentiel meningsdannelse. Den muliggør en skelnen mellem tre eksistentielle domæner som henholdsvis sekulære, spirituelle eller religiøse, relateret til tre dimensioner, knowing (kognition), doing (praksis) og being (betydning). Modellen har fungeret som underliggende struktur for datagenerering i begge studier i udarbejdelsen af henholdsvis interviewguide og spørgeskema (Hall, Meador, \& Koenig, 2008). Distinktionen mellem såvel de tre domæner som de tre dimensioner skabte muligheden for både heuristisk og analytisk at arbejde med aspekter af eksistentiel mening, som i vores empiriske arbejde kom til udtryk på forskellige måder. Tanker om eksistens og mening kom i vores studier således til udtryk i interview eller felt-samtaler eller som spørgeskema-afkrydsninger, hvor modellens linse bidrog til at strukturere analyserne af den komplekse empiri i begge studier. Prinds fokuserede på, om overvejelser relateret til eksistentiel meningsdannelse overhovedet intensiveredes blandt danske nybagte mødre (som havde født enten til tiden eller for tidligt), og hvordan de i givet fald kom til udtryk. Moestrup fokuserede på, hvordan mennesker, der skal dø, og deres pårørende oplever, tænker over og handler i relation til eksistentielle aspekter som død, tro, sociale relationer og mening med livet. 


\section{Meaning Making Matrix (MMM)}

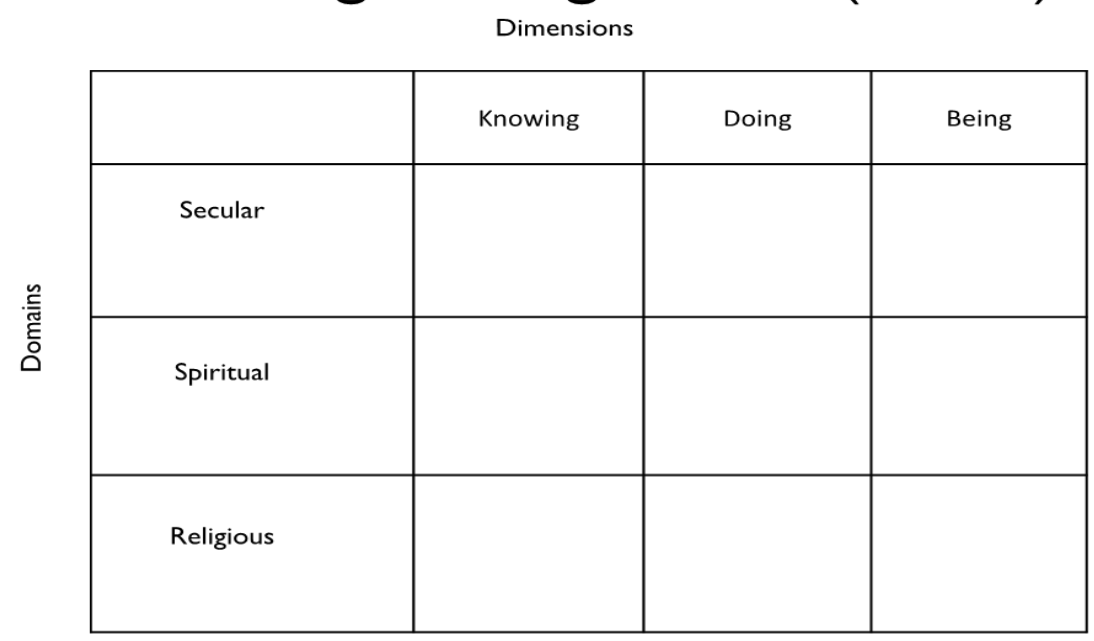

la Cour, P., \& Hvidt, N. C. (2010). Research on Meaning-Making and Health in Secular Society. Social Science \& Medicine, Volume 71, 1292-1129.

Model 1: Meaning Making Matrix (meningsdannelsesmodel)

\section{Metode}

I det følgende vil vi kort redegøre for metode og væsentlige fund i de inkluderede to studier, hvorefter vi ved hjælp af MMM vil strukturere vores sammenlignende refleksioner. Vores refleksioner er genereret gennem en flerårig periode, som startede, da vi påbegyndte hvert vores projekt, og de har varet ved efterfølgende som følge af fælles formidling af fund og analytiske pointer (2010-2018). På trods af dette parallelløb undervejs mellem de to studier er der her i artiklen primært tale om en sekundær analyse af vores oprindelige studier (Heaton, 2008). Ofte beror en sekundær analyse på enten kvantitative eller kvalitative data, hvorimod denne analyse trækker på primære data genereret fra begge forskningstilgange. Formålet med en sekundær analyse er her at argumentere for, at sammenlignelige træk i vores to primære studier kan udgøre et belæg for, at eksistentiel og åndelig omsorg kan være relevant ved livets begyndelse, ligesom det ses udøvet ved livets afslutning. Når det metodisk er både relevant og muligt, er det, som tidligere beskrevet, fordi vi trækker på samme strukturelle forståelse af meningsdannelsesmodellen. I denne artikel bygger vi videre på samme struktur ved at lade fund og analytiske pointer struktureres af modellens tre domæner og derefter 
diskutere fundene i lyset af begrebet transcendens, som det fortolkes hos Rubow og Johannesen-Henry. Rubow og Johannesen-Henry skriver om transcendens, at det er en overskridelse af det "denne verdenslige", rettet mod noget i en "anden verden". En anden verden er, som tidligere beskrevet ikke nødvendigvis præget af hverken kristne eller vestlige videnskabelige forståelser, men kan være præget af helt andre kosmologier. På baggrund af interviews med danske kræftsyge kvinder og pårørende til nyligt afdøde, argumenterer de for, at hverdagslivet i dødens nærvær er polydokst; det vil sige præget af en "mangfoldig-troenhed", som står i kontrast til en mere ortodoks rettroenhed. Det moderne menneske er således ikke orienteret monodokst i bestræbelsen på at forstå eller håndtere de livsudfordringer eller paradokser, som er livsvilkår i ethvert menneskes liv: Informanterne i deres studie trækker på mange forståelser fra ikke bare kristne eller naturvidenskabelige forståelser, men også fra mere eksotiske kosmologier og praksisser. Det empiriske grundlag for deres fortolkning af transcendens er endvidere baseret på data fra en dansk kontekst, hvilket øger præcisionen i relation til vores fund, som også er genereret i Danmark (Rubow \& Johannessen-Henry, 2010).

\section{Studiernes respektive datagenerering}

\section{Første studie: Begyndelsen på livet - eksistentiel mening hos danske mødre}

Med MMM som model og med udgangspunkt i et omfattende scoping review, samt i eksisterende spørgeskemaer om tro og eksistens, udviklede Prinds et. Al. et spørgeskema (Prinds, Hvidt, Mogensen, \& Buus, 2014). Spørgeskemaet indeholdte 46 spørgsmål og spørgsmålsbatterier, som handlede om eksistentiel mening, som for eksempel om, hvad der skaber mening og formål i livet og om det ændrer sig i forbindelse med, at man bliver mor (Prinds, Hvidtjorn, Mogensen, Skytthe, \& Hvidt, 2014). Det blev i 2011 sendt til alle mødre i Danmark, som i 2010 havde født før 32. graviditetsuge, samt det dobbelte antal kvinder, som i samme år havde født til termin. Der blev inkluderet både mødre, som havde født til tiden (Fuldterm mødre (FT)), og hvis forløb derfor kunne forstås som ukomplicerede i obstetrisk forstand, og mødre, som havde født for tidligt (Præterm mødre (PT)), og som derved kunne forventes at have oplevet en kompliceret og potentiel traumatisk fød- 
sel. En grundlæggende hypotese var, at PT mødre i højere grad ville tilslutte sig spørgeskemaets udsagn end FT mødre, fordi en generel antagelse er, at eksistentielle overvejelser intensiveres i mødet med svær sygdom og død (Benzies, MagillEvans, Hayden, \& Ballantyne, 2013; Golish \& Powell, 2003; Sundhedsstyrelsen, 2011; WHO et al 2012).

På baggrund af projektets overordnede formål og mødrenes svar, er det indtil videre i fire studier blevet undersøgt, i hvilken grad det at blive mor til et barn, enten født til tiden eller for tidligt, giver anledning til eksistentielle, religiøse og/ eller spirituelle overvejelser. Formålet med det første spørgeskemastudie var at undersøge, om det at blive mor i en sekulær kontekst giver anledning til en intensivering af overvejelser relateret til eksistentiel mening. I det andet spørgeskemastudie blev det undersøgt, om danske kvinder angiver spirituelle eller religiøse praksisser (bøn eller meditation) efter de er blevet mødre. Det tredje studie fokuserede på parforholdet og det fjerde, som endnu ikke er publiceret, undersøger selve fødslens betydning for den nybagte mor. I denne artikel henvises primært til fund i første og andet studie. Se tabel 1.

\section{Andet studie: Slutningen på livet - eksistentiel mening hos danske døende og deres pårørende}

I Moestrups studie blev data genereret gennem etnografisk inspireret feltarbejde på tre forskellige danske hospicer med brug af følgende kvalitative metoder: 1) 38 dages deltagerobservation fordelt på tre hospicer, 2) semistrukturerede interviews med 17 patienter indlagt på hospice, og 3) semistrukturerede interviews med ni pårørende til patienter indlagt på hospice. Se tabel 1. MMM gjorde det muligt at inkorporere de mange forskellige tilgange til tro og ikke-tro, som patienter og pårørende kunne give udtryk for.

Analyserne i Moestrups studie resulterede i tre genkommende temaer; døden, sociale relationer og tro. Igennem følgende delanalyser blev deltagernes måder at forholde sig til disse tre forskellige eksistentielle aspekter på demonstreret. 


\begin{tabular}{|l|l|l|l|}
\hline & Forskningsmetode & Patientgruppe & Alder \\
\hline Livets & $\begin{array}{l}\text { National } \\
\text { spørgeskemaundersøgelse } \\
\text { blandt 913 mødre, der havde født } \\
\text { i perioden 6-18 måneder før } \\
\text { undersøgelsen }\end{array}$ & $\begin{array}{l}\text { Mødre, som i 2010 } \\
\text { havde født enten før } \\
\text { 32. graviditetsuge } \\
\text { eller til termin }\end{array}$ & Gennemsnitlig 29,6 år \\
\hline Livets afslutning & $\begin{array}{l}\text { Deltagerobservation på 3 } \\
\text { hospicer samt semistrukturerede } \\
\text { interviews }\end{array}$ & $\begin{array}{l}\text { Indlagte } \\
\text { hospicepatienter (17) } \\
\text { og pårørende (9) }\end{array}$ & $\begin{array}{l}\text { Gennemsnitlig alder for } \\
\text { Gennem 62 år } \\
\text { pårørende 51 år }\end{array}$ \\
\hline
\end{tabular}

Tabel 1: Deltagere i de to projekter

\section{Resultater}

Resultater fra den sammenlignende analyse præsenteres i nedenstående to afsnit, som fokuserer på, hvordan livets begyndelse og afslutning vikles ind i hinanden: Det første afsnit omhandler, hvordan både livets begyndelse og afslutning kan opleves som begivenheder, der aktualiserer overvejelser om eksistentiel mening i sekulær forstand (som tilhører det sekulære domæne i den strukturerende model MMM). Begge begivenheder aktualiserer i al deres biologiske selvfølgelighed store og væsentlige livsspørgsmål om for eksempel meningsfuldhed, livsvalg og ansvar i livet. Det næste afsnit fokuserer på, hvordan også spirituelle og/eller religiøse orienteringer kan komme til syne i forbindelse med livets begyndelse og afslutning (som tilhører henholdsvis det religiøse og spirituelle domæne i modellen). 


\section{Livets begyndelse og afslutning: Sekulære eksistentielle viklinger}

\section{Hos danske mødre}

Formålet med det første spørgeskemastudie var at undersøge, om det at blive mor i en sekulær kontekst giver anledning til en intensivering af overvejelser relateret til eksistentiel mening.

I dette studie var der særligt fokus på overvejelser, som er relateret til knowing- og being dimensionerne i meningsdannelsesmodellen (se model 1). Danske nybagte mødre blev spurgt, om de oplevede, at 1) Mening og formål i livet havde ændret sig, efter de var blevet mødre, dernæst om de tænkte mere på 2) Livets sårbarhed, 3) Liv og død, 4) Ansvar og til sidst, om de tænkte mere på 5) "Noget større end mig selv". Generelt viste svarene på disse spørgsmål en meget ligelig tilslutning til udsagnene blandt de to grupper af førstegangsmødre (dem, der havde født prætermt versus til termin). Mere end 75\% af mødrene mente, at deres tanker om liv og død havde ændret sig. 86\% tænkte mere på livets sårbarhed, 75\% tænkte mere på liv og død og 64\% tænkte på "noget større end sig selv". Det blev på den baggrund konkluderet, at danske førstegangsmødres eksistentielle overvejelser intensiveres. I modsætning til studiets hypotese kunne det desuden konkluderes, at overvejelserne intensiveredes i næsten samme grad hos PT og FT mødre.

\section{Hos danske døende og deres pårørende}

Af Moestrups analyser af den samlede empiri (transskriptioner af interviews og feltnoter fra deltagerobservation) fremgik det bl.a. tydeligt, hvordan de døende i deres eksistentielle overvejelser fandt mening i livet tæt på døden ved at fokusere på "livet". Patienterne på hospice erkendte og var helt bevidste om, at de skulle dø i nær fremtid; men de var samtidig dybt vemodige, sorgfulde og ikke klar til at skulle forlade livet. Der viste sig at være en skelnen mellem frygten for selve dødsprocessen og angsten for dødens intethed (Moestrup, 2015). Enkelte patienter gav således udtryk for en bekymring over, hvordan den allersidste tid ville forløbe, som f.eks. Einer, der fortalte: "når jeg nu skal dø, så skal det være uden for mange smerter og så skal den sidste tid være sådan, at vi kan holde det ud...så skal det være med værdighed...så skal det være sådan, at jeg ikke ligger som sådan en eller anden grøntsag, 
der ikke kan kontaktes og som ikke har nogen mening om noget". Der var kun en enkelt patient, der gav ud 7 tryk for en vis frygtsomhed over for dødens intethed. De fleste fortalte derimod direkte adspurgt, at de ikke var bange for døden. Dette var overraskende i henhold til eksempelvis den ame $\neg$ rikanske psykiater Irvin Yaloms beskrivelser af dødsangst som et eksistentielt grundvilkår (Yalom, 1980; Yalom, 2008). De fleste patienter fortalte således, at de ikke ønskede at bruge deres sidste tid på at tale om og tænke på døden. De ønskede at fokusere på relationer og på "livet" - det liv, der stadig var tilbage og det liv, der havde været. Anna, som var døende, fortalte således om relationen med sin voksne søn: "Vi har nået en anden tæthed nu - på en anden måde, ikke - altså man kan jo sige, at $i$ og med ens børn bliver voksne, så slutter noget af den der intimitetssfxere man har, når de er små [...] men det vil jeg sige - nu bliver der (igen) åbnet op på en anden måde... jamen det er dejligt, at han kan sidde og vi kan sidde og holde hinanden $i$ hånden lige så stille $i$ en time... " (Moestrup, 2015; Moestrup, 2015).

\section{Livets begyndelse og afslutning: Spirituelle/religiøse viklinger}

\section{Hos danske mødre}

I det andet spørgeskemastudie blev det undersøgt, hvorvidt mødrene brugte bøn og meditation, og således var det i særlig grad doing-dimensionen i MMM, der var fokus på i dette studie. Spørgsmålene, der blev anvendt, har tidligere været anvendt i f.eks. de europæiske værdiundersøgelser, men i denne version blev der yderligere givet mulighed for uddybelse ved, at respondenterne kunne angive, hvordan de forstod bøn og/eller meditation. Resultatet viste, at $65 \%$ af mødrene svarede bekræftende til, at de af og til beder eller mediterer. Endvidere blev det påvist, at flere mødre praktiserede bøn end meditation. Det var i særlig grad svarmuligheden bøn som en indre dialog henvendt til Gud, som blev afkrydset. Det blev derfor konkluderet, at en overraskende stor gruppe af nybagte mødre ikke blot gør sig overvejelser om mening og eksistens på et sekulært niveau (som var resultatet i spørgeskemaundersøgelsens første studie), men at mange også har haft en bøns- eller meditationspraksis relateret til de religiøse og spirituelle domæner i model MMM . 


\section{Hos danske døende og deres pårørende}

Analyser i Moestrups studie demonstrerede, hvordan de døende ofte gav udtryk for en svag og usikker tilgang til tro både i forhold til at fortælle, hvad de egentlig troede på, og i relation til religiøs og spirituel handlen svarende til knowing og doing dimensionen i MMM. Alligevel tilkendegav de fleste patienter et intensiveret fokus på tanker om tro og et ønske om støtte fra en transcendent verden, hvilket kan relateres til being-dimensionen. De fleste beskrev således, hvordan tanker om tro inspireret fra eksempelvis både kristendom, buddhisme og egne private konstruktioner som forklaring på liv og død var intensiveret i forbindelse med den alvorlige sygdom. Denne individuelle tro var for mange en kilde til støtte, hvilket bl.a. blev udtrykt som, at troen gav en oplevelse af fred i sindet, af ro eller en følelse af ikke at være alene. Hermed kunne den enkeltes tro fungere som et positivt værktøj i håndteringen af den svære situation som døende. Andre patienter beskrev som modsætning her $\neg$ til, hvordan det var umuligt for dem at forstå Guds mening med deres lidelse. De fandt Guds handlinger grusomme og meningsløse, hvilket afstedkom nega $\neg$ tive følelser som vrede, skuffelse og sorg. Idet refleksioner over tro således kunne være forankret i dybe følelser og influere både negativt og positivt på livskvalitet i den sidste del af livet, argumenteres der i Moestrups forskning for nødvendigheden af eksistentiel og åndelig omsorg med et særligt fokus på patienternes individuelle tro i den palliative indsats (Moestrup \& Hvidt, 2016).

Andre analyser af Moestrups forskning påpeger, at patienter, der skulle dø, og deres pårørende uanset religiøst tilhørsforhold både alene og sammen skabte nye fortællinger med fokus på opretholdelse af en sekulær og/eller transcendent re $\neg$ lation med hinanden, der kunne række ind i og ud over døden. Det kunne være fortællingen om, hvordan den døende også efter døden ville være til stede i erindringen hos den pårørende, konstruktioner om forestillinger om efterliv, om skabelsen af minder eller om gravstedets betydning. Ved at skabe en fortælling, der hermed indeholdt en forestilling om en fortsat forbindelse efter døden, hvor den afdøde og de efterlevende gennem nye "mødesteder "og "mødeformer" kunne deltage i hinandens liv og efterliv, skabte deltagerne et nyt meningsgivende plot i deres fortællinger om de indbyrdes relationer: "Den døende forsvinder ikke!"(Moestrup, Hvidt, \& Hansen, 2014). Hermed rekonstru 7 eres betydning og forståelse af deres hidtidige relation, så den kunne række ud over et fysisk og ind i et transcendent samvær, som minder om den oplevelse af trancendens som er beskrevet af Rubow og Johannesen i relation til deres informanter. Når delta- 
gernes hidtidige relation således genbekræftes i en ny fortælling, rekonstrueres tilsvarende en ny mening i livet og måske i mødet med døden. Moestrup argumenterer på den baggrund for, hvordan et fokus på og en understøttelse af dette mulige transcendente plot i palliativ praksis måske vil kunne bidrage med støtte til både patienter og pårørende i relation til skabelse af mening i mødet med den forestående og måske meningsløse død.

\section{Diskussion}

Med udgangspunkt i vores forskellige empiri og vort fælles teoretiske fundament "the Meaning Making Matrix" vil vi diskutere fund fra begge studier både i relation til sekulære viklinger og i relation til spirituelle/religiøse. Særligt vil vi diskutere den intensivering af tanker om tro og mening, som vi fandt i begge studier, i forhold til begrebet transcendens. Det synes i begge studier udtrykt, at dødens nærvær eller fødslens nærvær er begivenheder, som kan sætte deltagerne i forbindelse med noget transcendent, som forvandler livet for en stund. Det kan både være forbindelse til noget religiøst eller spirituelt i en konkret bøns- eller meditationspraksis, men det kan også være mere sekulære forståelser eller erfaringer af, hvordan livet perspektiveres af simpelthen at stå ved kanten af det: Hvad var før barnets fødsel? Hvad kommer efter min død?

Vi vil på den baggrund diskutere, hvordan vi mener eksistentiel/åndelig omsorg potentielt kan være relevant på samme måde ved livets begyndelse som ved livets afslutning.

\section{Livets afslutning og begyndelse og en transcendent forbindelse}

At stå ved kanten af livet og kigge på døden kan forvandle livet for en stund: Moestrup et al fandt således, at informanterne udtrykte vemod over at skulle forlade livet, men ikke frygtede dødens "intethed". Denne samtidige optagethed af livets mening og dødens realitet kan også ses som et udtryk for, hvordan livet strækker sig ind i forestillinger om efterliv. Flere informanter udtrykte forestillinger om at vedblive med at have en social relation med en afdød. Det kan ses som et udtryk for, at en transcendent forbindelse overlever - en forbindelse mellem denne og den anden verden. Også refleksioner over tro, særligt i modellens being-dimension, blev udtrykt og kunne have væsentlig både negativ og positiv betydning for de døendes livskvalitet i den sidste del af livet. På denne måde kan forbindelsen til 
noget transcendent bidrage til at omdanne døden fra at være en uundgåelig afslutning på livet, til i stedet at have en fortsættelse, der rækker ud over døden. Den transcendente forbindelse kan hermed i dette perspektiv skabe elementer af mening med og i døden, både for den, der selv er døende og for den pårørende.

Ligeså kan fødslen, som det vilkår den er, nemlig starten på et menneskes tilsynekomst i verden, omdannes til at være en begivenhed, der rækker forud for fødslen, og tydeliggøre meningsgivende elementer. Fødslen af et barn er således ikke blot et spørgsmål om nu og her, men perspektiverende for den fortid, man har haft, og den fremtid man får. Ligesom døden kan synliggøre en transcendent forbindelse og gå fra at være en uundgåelig afslutning på livet til at række ud over døden, kan fødslen også synliggøre en transcendent forbindelse og være ikke blot den absolutte begyndelse på livet, men række ud over fødslen. Livet ses i forskellige lys henholdsvis før og efter et barns tilsynekomst i verden, men det kan også udfordre livets begyndelseskant i mere symbolsk forstand. Spørgsmål om hvor livet egentlig kommer fra, hvor barnet var, inden det kom til syne i verden, eller forundring over menneskets fødthed i det hele taget kan dukke op, og dermed skabe en form for transcendent forbindelse eller bevidsthed (Arendt, 1958). Flere studier med fokus på på moderperspektivet taler ligefrem om fødslen, ikke blot som barnets fødsel, men om at en kvinde selv bliver genfødt, hvilket kan forstås som en radikal transcendenisering af fødslen som begivenhed, fordi de refleksioner, der kan række udover fødslen, her næsten gøres biologiske (Callister \& Khalaf, 2010; Odent, 2002). Ligeledes kan de nybagte mødres store tilslutning til udsagn om at tænke mere på noget større end sig selv (64\%) ses som udtryk for, hvordan fødslen kan synliggøre noget transcendent i livet. At "noget større end mig selv" får mere betydning for respondenterne, som det ses i et af svarene, kan i sig selv være helt polydokst, altså udtrykke at respondenterne orienterer sig i forskellige kosmologier: Det kan indebære alt lige fra relationen med en personlig gud, følelsen af at være forbundet med universitet eller en ny enhed med ens nyfødte. Det kan vi dog ikke konkludere mere præcist på baggrund af spørgeskema-svarene.

I det efterfølgende spørgeskema-studie, som fokuserede på doing-dimensionen, fandt vi stor tilslutning til både bøn og meditation (65\%), og blandt de mødre, der tilsluttede sig, bekræftede flere, at de både bad og mediterede (16\%). Dette kan også ses som et polydokst udtryk for, at deres praksisser har udgangspunkt i flere kosmologier og kulturelle forstålser, som sagtens kan sameksistere (Prinds, Hvidtjorn, Skytthe, Mogensen, \& Hvidt, 2016). Det kan synes mere radikalt med den store tilslutning til bøn og meditation, end den store tilslutning i første studie til svarkategorierne om ansvar, sårbarhed eller mening. Det kan virke så selvføl- 
geligt, at netop disse overvejelser og følelser aktualiseres. Alligevel kan også de forstås som livsforvandlende i den forstand, at de på en måde oplyser de livsvilkår, som synes mere slørede i et almindeligt hverdagsliv: For eksempel tanker om hvor vi kommer fra, at døden ER en reel mulighed selv i et velfærdssamfund, og at vores ansvar i livet vokser i takt med, at et barn nu er tilstede i vores nære verden (Brudal, 2000; Yalom, 2008).

\section{Forståelser af eksistentiel og åndelig omsorg i retningslinjerne for svangreomsorg}

Overordnet peger fundene i vore studier på, at danske nybagte mødre og døende samt pårørende synes at reflektere over, hvad det $\mathrm{i}$ egentlig forstand vil sige at være menneske. At drage omsorg for sådanne tanker er, som beskrevet tidligere i denne artikel, allerede defineret i Sundhedsstyrelsens faglige retningslinjer for den palliative indsats i 1999, hvor det netop beskrives som eksistentiel og åndelig omsorg (Sundhedsstyrelsen, 1999). Hensigten i retningslinjerne er, at der i relation til slutningen på livet er systematisk fokus på eksistentielle/åndelige behov, på linje med fysiske, psykiske og sociale behov hos såvel patienter som pårørende, hvilket Moestrups studie i høj grad støtter op om. En nyligt publiceret dansk artikel udfolder yderligere, hvordan eksistentiel og åndelig omsorg kan forstås, og argumenterer for relevansen heraf i Danmark (Hvidt et al 2018).

Imidlertid er der i relation til begyndelsen på livet, nemlig i Sundhedsstyrelsens anbefalinger for svangreomsorgen i Danmark, ingen tydelig tradition for at yde eksistentiel eller åndelig omsorg. (Sundhedsstyrelsen, 2013). Sundhedsstyrelsens anbefalinger for gravide, fødende og barslende fokuserer på behov hos kvinder, børn og familier relaterede til fysisk, psykisk og social sundhed, hvorimod eksistentielle behov - eller åndelig omsorg - ikke nævnes. Det kan undre os, at den eksistensfilosofiske fordring fra Kierkegaard om at reflektere over, hvad det vil sige at være i live, ikke efterleves i de danske anbefalinger for svangreomsorg, der ellers omhandler en af de livsbegivenheder, hvor livet (og døden) kan virke mest intenst.

I en Kirkegaardsk ånd ville det være naturligt, at man også i svangreomsorgens arbejde systematisk adresserede spørgsmål om, hvad det i egentlig forstand vil sige at være menneske og forståelsen af livsværdier. At stå ved begyndelsen til et nyt liv kan ses som en proces, hvor jordemødre, læger og andre i svangreomsorgen med fordel kunne arbejde som fødselshjælpere også i sokratisk forstand: At 
hjælpe medmennesket til at bringe egne refleksioner til live. Det er eksistentiel og åndelig omsorg, der kan have, men ikke nødvendigvis indebærer, religiøse og/ eller spirituelle aspekter. Som la Cour og Hvidt påpeger med MMM, er det netop karakteristisk for en dansk kontekst at være mere sekulært orienteret. Eksistentiel og åndelige omsorg kan dog også indebære at få kendskab til refleksioner og praksisser, som indebærer bagvedliggende religiøse og spirituelle forståelser, som kan være polydokse, som Rubow og Henry-Johannesen påpeger. Som beskrevet i Moestrups studie og i flere andre danske studier omhandlende svært syge og døende, er det vist, at religiøs tro kan have betydning som både trøst og håndteringsstrategi.

At drage eksistentiel og åndelig omsorg kan således betyde, at være "fødselshjælpere" i relation til de overvejelser, der kan blive fremtrædende ikke blot ved livets afslutning, men tilsyneladende også ved livets begyndelse.

\section{Eksistentiel og åndelig omsorg som sundhedsfremme}

I retningslinjerne for den palliative indsats er der primært fokus på at styrke livskvalitet hos patienter og pårørende i forbindelse med lidelse, udfordringer og "... og andre problemer af både fysisk, psykisk, psykosocial og åndelig art." (Sundhedsstyrelsen, 2017 s. 6). Imidlertid kan der også være et andet sigte med systematisk at adressere eksistentielle og åndelige udfordringer og refleksioner, nemlig det sundhedsfremmende. På trods af den ifølge sundhedslovens §1 lovmæssige forpligtelse til at arbejde sundhedsfremmende er der ofte også i sundhedsloven primært fokus på bio-psyko-sociale elementer (Ældreministeriet, 2016). I forsøget på at skabe en bredere forståelse af sundhed, forsøger WHO at ændre forståelsen af mental sundhed fra en stram medikaliseret forståelse til en mere inkluderende. I en rapport med en aktionsplan for perioden 2013-2020 defineres mental sundhed som: "... a state of well-being in which the individual realizes his or her own abilities, can cope with the normal stresses of life, can work productively and fruitfully, and is able to make a contribution to his or her community" (WHO, 2004 s. 11). Her lægges vægt på sundhed som evnen til at realisere muligheder og håndtere stressorer i livet (Antonovsky, 1987). Også i Danmark lægges der nu vægt på sundhedsfremmende forståelser og initiativer, som kan fremme mental sundhed. (Koushede, 2015). Der er altså organisatorisk, både i WHO og i den danske sundhedsstyrelse, en bred forståelse af sundhed, som en tilstand, der også kan faciliteres af meningsdannelse (eksistentiel) eller hæmmes på mangel af samme. Det ses både i anbefalingerne for den palliative omsorg og i det nyere fokus på mental sundhed. I relationen til 
indsatsen i sundhedsvæsenet på disse to felter tillægges eksistentiel meningsdannelse en tydelig betydning for sundhed - men det er, som vist, ikke tilfældet $\mathrm{i}$ svangreomsorgen. Tanker om mening, værdier og tro burde gennem denne sundhedsfremmende linse adresseres, så også kvinder og pårørende i svangreomsorgen bedre kan opnå mental sundhed. Som filosoffen Ivan Illich (1926-2002) pointerede er målet $i$ et sundt liv at kunne håndtere det modigt og selvstændigt, hvilket besværliggøres $i$ et sundhedsvæsen, der er optaget af at gøre sundhed til noget, vi kan måle: "Rather than being healthier, which always means being more autonomous, your client, through your care, becomes more dependent, more a patient" (Illich, 1982)

\section{To opsummerende argumenter}

Således er der flere grunde til, at eksistentielle aspekter ved det at være menneske bør udforskes, og at eksistentiel og åndelig omsorg må adresseres systematisk også i svangreomsorgen, hvilket kan opsummeres i følgende to argumenter:

Det eksistentielle/åndelige argument: Når tanker om mening og formål og værdier udfordres i patienters liv, her hos nybagte mødre, synes det relevant at gøre disse tanker til genstand for udforskning og adressere dem direkte i sundhedsvæsenets omsorg. At blive udfordret på hvad det $\mathrm{i}$ egentlig forstand vil sige at være menneske bør adresseres, fordi eksistentielle aspekter, herunder også religiøse og spirituelle forståelser og praksisser, har vist sig at have betydning for mange danske patienter.

Det sundhedsfaglige argument: En del forskning peger på, at eksistentielle og åndelige aspekter af menneskers liv har stor betydning for livslængde, sygdom og mestringsevne i livet (Koenig et al., 2012; Thygesen et al., 2012). Vi ved ganske lidt om, hvad disse aspekter betyder i relation til svangrefeltet: Hvor meget fylder sådanne tanker eller praksisser for eksempel i forbindelse med prænatal screening? Udviklingen af fødsels-angst, depression eller PTSD? Eller hvordan påvirker de sygdomsopfattelser mere bredt forstået? Som en særlig væsentlig del af det sundhedsfaglige argument fremstår det sundhedsfremmende arbejde: Hvis den mentale sundhed i stigende grad er udfordret som følge af en stram medikaliseret forståelse, så synes det helt oplagt at udforske og adressere eksistentielle og åndelige aspekter af det, at være et sundt menneske også i relation til livets begyndelse. 


\section{Konklusion: Resonans mellem livets begyndelse og afslutning}

Som haikudigteren, som er citeret i starten af artiklen, fremfører det, finder også vi i vores sammenlignende refleksion, at liv og død bøjer sig ind mod hinanden ved livets indgang og udgang og lyser derved hinanden op. Ja, ikke blot det både livets begyndelse og afslutning kan skabe forbindelse til noget transcendent, som kan have bund i forskellige kosmologiske forståelser og praksisser. Tanker om livets sårbarhed og død fylder for de fleste nybagte mødre i det ene studie, hvorimod tanker om hverdagslivets mening og fokus på livet fylder for de døende i det andet studie. Livets begyndelse og afslutning virker dermed som konkrete erfaringer, som i al deres biologiske radikalitet vikler sig ind i hinanden, nemlig ved et nyt menneskes tilsynekomst i verden eller ved et menneskes udgang af verden. De illuminerer hinanden, således at dødens nærvær synes mere tydeligt ved livets begyndelse, og således at livet selv synes mere tydeligt, jo tættere døden kommer.

Med begrundelse i ovenstående to sammenfattende argumenter, det eksistentiellelåndelige og det sundhedsfaglige, mener vi derfor, at eksistentiel og åndelig omsorg kan være relevant ved livets begyndelse på samme måde som ved livets afslutning. Måske kunne man med fordel i sundhedsforskningen omkring livets begyndelse skæve til, hvordan forskning, uddannelse og den faktiske eksistentielle og åndelige omsorg systematisk adresseres i det palliative felt, ikke som en singleprofessionel indsats eller ansvar, men ofte i tværvidenskabelige og tværprofessionelle samarbejder, som rækker ud over sundhedsvidenskabelige forståelser af, hvad det vil sige at være et sundt eller sygt menneske. Det første og sidste åndedrag i livet er som et koncentrat af henholdsvis livets begyndelse og afslutning. Åndelighed i denne forstand må være forskning og praksis værd også i sundhedsvæsenets indsats for gravide, fødende og nye familier.

\section{Referencer}

Andersen, P. B., \& Lüchau, P. (2011). Individualisering og aftraditionalisering af danskernes religiøse værdier. In Gundelach PR (Ed.), Små og store forandringer - Danskernes værdier siden 1981. København: Hans Reitzels Forlag.

Antonovsky, A. (1987). Unravelling The Mystery of Health - How People Manage Stress and Stay Well. San Fransisco: Jossey-Bass Publishers.

Arendt, H. (1958). Menneskets vilkår. Denmark: Gyldendal. 
Benzies, K. M., Magill-Evans, J. E., Hayden, K. A., \& Ballantyne, M. (2013). Key components of early intervention programs for preterm infants and their parents: a systematic review and meta-analysis. BMC Pregnancy Childbirth, 13:1. doi: 10.1186/1471-2393-1113-S1181S1110.

Binswanger, L. (1963). Being-in-the-world: Selected papers of Ludwig Binswanger. New York: Basic Books.

Birkler, J. (2010). Filosofi \& jordemoderkunst. Esbjerg: UC Vest Press.

Brudal, L. F. (2000). Psykiske reaksjoner ved svangerskap, fødsel og barseltid. Bergen: Fagbokforlaget Vigmosestad \& Bjørke AS.

Budin, W. C. (2001). Commentary. Birth and death: opportunities for self-transcendence. Journal of Perinatal Education, 10(2), 38-42. https://doi.org/10.1624/105812401X88192

Bussing, A., Janko, A., Baumann, K., Hvidt, N. C., \& Kopf, A. (2013). Spiritual needs among patients with chronic pain diseases and cancer living in a secular society. Pain Med., 14(9), 1362-1373. https://doi.org/10.1111/pme.12198

Callister, L. C. (2004). Making meaning: women's birth narratives. The American Journal of Maternal/Child Nursing, 33(4), 508-518. https://doi.org/10.1177/0884217504266898

Callister, L. C., \& Khalaf, I. (2010). Spirituality in Childbearing Women. The Journal of Perinat Education, 19(2), 16-24. doi:10.1624/105812410X105495514.

Crowther, S., Smythe, E., \& Spence, D. (2014). Kairos time at the moment of birth. Midwifery, 005.

Fishman, J. (1980). Social theory and ethnography: Language and ethnicity in Eastern Europe. In P. E. Sugar (Ed.), Ethnic diversity and conflict in Eastern Europe (pp. pp. 347-371). Oxford: Clio Press.

Frankl, V. E. (1963). Man's search for meaning: An introduction to logotherapy. Oxford: Washington Square Press.

Golish, T. D., \& Powell, K. A. (2003). 'Ambiguous loss': Managing the dialectics of grief associated with premature birth. Journal of Social and Personal Relationships, 20(3), 309-334. https://doi.org/10.1177/0265407503020003003

Hall, D. E., Meador, K. G., \& Koenig, H. G. (2008). Measuring religiousness in health research: review and critique. J Relig Health., 47(2), 134-163. doi: 110.1007/s10943-1000819165-10942. Epub 12008 Mar 10946.

Hansen, F. T. (2016). At undres ved livets afslutning. Om brug af filosofiske samtaler i palliativt arbejde. København: Akademisk Forlag.

Health, Nordic Research of Faith and (2017). Completed Research Projects: http://faithhealth.org/?cat $=61$

Heaton, J. (2008). Secondary analysis of qualitative data: an overview. Historical Social Research, 33(3), 33-45. doi: 10.12759/hsr.33.2008.3.33-45

Hodgkinson, E. L., Smith, D. M., \& Wittkowski, A. (2014). Women's experiences of their pregnancy and postpartum body image: a systematic review and meta-synthesis. BMC Pregnancy Childbirth, 14, 330. https://doi.org/10.1186/1471-2393-14-330

Illich, I. (1982). Medicalization and primary care. J R Coll Gen Pract., 32(241), 463-470.

Jacobsen, B. (2007). Invitation to Existential Psychology. A psychology for the unique human being and its applications in therapy. Chichester: John Wiley \& Sons Ltd,

Kaufman, S. R., \& Morgan, L. M. (2005). The Anthropology of the Beginnings and Ends of Life. Annual Review of Anthropology, 34, 317-341. https://doi.org/10.1146/annurev.anthro.34.081804.120452 
Kierkegaard, S. (1962). Synspunktet for min forfatter-virksomhed. In Kierkegaards samlede værker. (Vol. Bind 18). København: Gyldendal.

Koenig, H. G., King, D. E., \& Carson, V. B. (2012). Handbook of Religion and Health (Second edition ed.). New York: Oxford University Press.

Koushede, V. (2015). For mental sundhed - et nyt perspektiv. København: Statens Institut for Folkesundhed.

la Cour, P., \& Hvidt, N. C. (2010). Research on meaning-making and health in secular society: Secular, spiritual and religious existential orientations. Social Science \& Medicine, 71(7), 1292-1299. https://doi.org/10.1016/j.socscimed.2010.06.024

Miller, T. (2005). Making sense of Motherhood. New York: Cambridge University Press. https:// doi.org/10.1017/CBO9780511489501

Moestrup, L. (2015). I dødens nærvær: en kvalitativ undersøgelse af, hvordan patienter på hospice og deres pårørende forholder sig til eksistentielle aspekter af livet tæt på døden. Ph.d afhandling, Syddansk Universitet.

Moestrup L, H. H. (2015). Existential Concerns about Death: A Qualitative Study of Dying Patients in a Danish Hospice. American Journal of Hospice and Palliative Medicine 32(4), 427-436. https://doi.org/10.1177/1049909114523828

Moestrup, L., \& Hvidt, N. C. (2016). Where is God in my dying? A qualitative investigation of faith reflections among hospice patients in a secularized society. Death Studies, 40(10), 618-629. https://doi.org/10.1080/07481187.2016.1200160

Moestrup, L., Hvidt, N. C., \& Hansen, H. P. (2014). Hun forsvinder ikke - et kvalitativt studie af døende patienters og pårørendes overvejelser om en fortsat relation efter døden. Klinisk Sygepleje, 30(4), 62-79.

Odent, M. (2002). The first hour following birth: Don't wake up the mother! Midwifery today with international midwife, 61, 9-12.

Prinds, C. (2014). Motherhood transition through an existential lens - meaning-making among Danish first-time mothers. Ph.d afhandling, Syddansk Universitet.

Prinds, C., Hvidt, N. C., Mogensen, O., \& Buus, N. (2014). Making existential meaning in transition to motherhood-A scoping review. Midwifery, 30(6), 733-741. https://doi. org/10.1016/j.midw.2013.06.021

Prinds, C., Hvidtjorn, D., Mogensen, O., Skytthe, A., \& Hvidt, N. (2014). Existential Meaning Among First-Time Full-Term and Preterm Mothers: A Questionnaire Study. J Perinat Neonatal Nurs., 28(4), 271-279. https://doi.org/10.1097/JPN.0000000000000060

Prinds, C., Hvidtjorn, D., Skytthe, A., Mogensen, O., \& Hvidt, N. C. (2016). Prayer and meditation among Danish first time mothers-a questionnaire study. BMC Pregnancy Childbirth., 16:8.(doi), 10.1186/s12884-12016-10802-12886.

Rosen, I. (2009). I'm a Believer - But I'll Be Damned if I'm Religious : Belief and Religion in the Greater Copenhagen Area: A Focus Group Study. (PhD), Lunds University, Centrum för teologi och religionsvetenskap, Lunds University.

Rubow, C., \& Johannessen-Henry, C. T. (2010). Variationer af liv i døden: Trancendenser i hverdagslivets (nye) polydoksi. Tidsskrift for Forskning i Sygdom og Samfund, 12, 135-153. https://doi.org/10.7146/tfss.v7i12.2960

Schnell, T. (2009). The Sources of Meaning and Meaning in Life Questionnaire (SoMe): Relations to demographics and well-being. The Journal of Positive Psychology, 4(6), 483-499. https://doi.org/10.1080/17439760903271074 
Sundhedsstyrelsen. (1999). Faglige retningslinjer for den palliative indsats: omsorg for alvorligt syge og døende. København. Sundhedsstyrelsen.

Sundhedsstyrelsen (2011). Anbefalinger for den palliative indsats. København. Sundhedsstyrelsen.

Sundhedsstyrelsen (2013). Anbefalinger for svangreomsorgen. København. Komiteen for Sundhedsoplysning.

Sundhedsstyrelsen (2017). Anbefalinger for den palliative indsats. København: Sundhedsstyrelsen.

Thygesen, L. C., Hvidt, N. C., Juel, K., Hoff, A., Ross, L., \& Johansen, C. (2012). The Danish religious societies health study. Int J Epidemiol., 41(5), 1248-1255. https://doi.org/10.1093/ ije/dyr089

van Deurzen-Smith, E. (1984). Existential therapy. In W. Dryden (Ed.), Individual therapy in Britain. London: Harper \& Row.

Vries, R. G. d. (1981). Birth and Death: Social Construction at the Poles of Existence. Social Forces, 59 (Special Issue), 1074-1093. https://doi.org/10.1093/sf/59.4.1074

WHO, March of Dimes, Partnership for Maternal, Newborn \& Child Health, Save the Children (2012). Born Too Soon: The Global Action Report on Preterm Birth. Retrieved from Geneva:

WHO (2004). Promoting mental health: concepts, emerging evidence, practice: summary report / a report from the World Health Organization, Department of Mental Health and Substance Abuse in collaboration with the Victorian Health Promotion Foundation (VicHealth) and the University of Melbourne. http://www.who.int/mental_health/evidence/en/promoting_mhh.pdf.

WHO (2016). WHO recommendations on antenatal care for a positive pregnancy experience. Retrieved from WHO Press, World Health Organization, Switzerland

Yalom, I. (1980). Existential Psychotherapy. New York: Basic Books.

Yalom, I. (2008). Som at se på solen - at leve med døden. København: Hans Reitzels Forlag

Zuckerman, P. (2008). Society without God: What the Least Religious Nations Can Tell Us about Contentment. New York: NYU Press.

Sundheds- og Ældreministeriet (2016): Bekendtgørelse af sundhedsloven, LBK nr. 118. 